\title{
Contaminated Toothbrushes and Potential COVID-19 Transmission: Concerns and Recommendations
}

\author{
Andrea Vergara-Buenaventura ${ }^{1, \odot ~ C a r m e n ~ C a s t r o-R u i z ~}{ }^{1}$ \\ ${ }^{1}$ Department of Periodontology, School of Dentistry, Universidad \\ Address for correspondence Andrea Vergara-Buenaventura, DDS, \\ Cientifica del Sur, Lima, Peru \\ MSc, PhD(s), Department of Periodontology, School of Dentistry, \\ Universidad Cientifica del Sur, Calle Cantuarias 398, 15048, \\ Miraflores, Lima, Perú (e-mail: avergarab@cientifica.edu.pe).
}

Eur J Gen Dent 2021;10:101-105.

\begin{abstract}
Substantial past evidence has demonstrated microbial contamination of oral devices and possible transmission of viral diseases, drawing attention to habits related to using and storing toothbrushes. Since toothbrushes are in intimate contact with the oral cavity, the question arises as to whether they can transmit COVID-19.

An electronic search was performed in four databases to identify relevant literature about the possible contamination or transmission of SARS-CoV-2 through toothbrushes until May 2021. Forty-five records were retrieved, and after a thorough search,

Keywords

- COVID-19 we found no articles reporting significant evidence. However, studies with other viral diseases have indicated that improper use and storage of toothbrushes could contribute to indirect disease transmission.

- contamination

- oral health

- SARS-CoV-2

Therefore, this narrative review supports the implementation of toothbrush disinfection and storage measures to minimize the risk of SARS-CoV-2 infection among cohab-

- toothbrushes itants and community settings. Finally, recommendations and a suggested protocol to

- transmission reduce the potential risk of transmission between cohabitants are provided.
\end{abstract}

\section{Introduction}

The severe acute respiratory syndrome coronavirus-2 (SARS-CoV-2) has caused the coronavirus disease 2019 (COVID-19) outbreak and a global concern. ${ }^{1-3}$ Most governments implemented strict measures to limit viral transmission such as isolation, personal protective equipment, and handwashing. ${ }^{1}$

Evidence has suggested that inadequate measures could indirectly contribute to COVID-19 infection between people living together, ${ }^{4}$ drawing attention to habits related to using and storing oral appliances. ${ }^{5-7}$ In the past, considerable evidence has demonstrated microbial contamination of toothbrushes and possible transmission of viral diseases to users. ${ }^{8-11}$ Like other microorganisms, SARS-CoV-2 has been detected in the oral mucosa, ${ }^{12,13}$ and saliva samples turn the oral cavity into an important route of transmission and potential reservoir of the virus. ${ }^{13-16}$ Since toothbrushes are in intimate contact with the oral cavity, the question arises as to whether they can transmit COVID-19. Not to mention that experts have suggested that a fecal-oral route of SARS-CoV-2 transmission is possible, with the potential to contaminate toothbrushes stored near the toilet. ${ }^{17,18}$

Therefore, the purpose of this review was to answer the following questions:

- Has SARS-CoV-2 been found on toothbrushes?

- Is there evidence of the transmission of the SARS-CoV-2 through toothbrushes?
DOI https://doi.org/ 10.1055/s-0041-1735762 ISSN 2320-4753 (c) 2021. European Journal of General Dentistry.

This is an open access article published by Thieme under the terms of the Creative Commons Attribution-NonDerivative-NonCommercial-License, permitting copying and reproduction so long as the original work is given appropriate credit. Contents may not be used for commercial purposes, or adapted, remixed, transformed or built upon. (https://creativecommons.org/licenses/by-nc-nd/4.0/). Thieme Medical and Scientific Publishers Pvt. Ltd. A-12, 2nd Floor, Sector 2, Noida-201301 UP, India 
Simultaneously, recommendations on toothbrush disinfection and storage based on other viral infections are given to reduce the potential risk of transmission between cohabitants.

\section{Material and Methods}

An electronic search was performed in Medline via PubMed, Embase, Scopus, and Scielo databases to identify relevant literature about the possible contamination or transmission of SARS-CoV-2 through toothbrushes until May 2021. The search strategy included the following terms: toothbrush, SARS-COV-2, and COVID-19. The complete search strategy, by database, is shown in - Table 1 .

The search was not limited to language restrictions or time and included all levels of evidence that reported the results of a study. Also, the references of selected articles were planned to be hand searched. Reviews, editorial, editor letters, personal opinions, congress abstracts, and animal studies were excluded.

Two review authors (A.V. and C.C.) were involved in title and abstract screening and article selection after full-text screening following the inclusion criteria. Articles that do not contain information regarding toothbrushes and SARS-CoV-2 were excluded. Full-text articles were evaluated to identify studies that met the inclusion criteria. The same authors performed the synthesis of the data extracted.

\section{Results}

A total of 45 records were retrieved from four databases. After the removal of duplicated articles, 29 articles remained for a title and abstract screening. After a thorough search, we found no articles reporting substantial evidence about contamination or transmission of SARS-CoV-through toothbrushes. - Fig. 1 shows the flowchart diagram for the search strategy used.

\section{Discussion}

The theory of a potential risk of SARS-CoV-2 infection by toothbrushes is based on aerosol and surface contamination studies. Van Doremalen et a ${ }^{19}$ detected that SARS-CoV-2 was viable for up to 3 hours in drops, 24 hours in cardboard, 48 hours in stainless steel, and 72 hours in plastics. Meanwhile, Santarpia et $\mathrm{al}^{20}$ reported that $70.6 \%$ of all personal items in quarantine rooms were positive for SARS-CoV-2.

Although the presence of SARS-CoV-2 in toothbrushes has not yet been reported, considerable past evidence has indicated that toothbrushes can be easily contaminated

Table 1 Search strategy

\begin{tabular}{|c|c|}
\hline $\begin{array}{l}\text { MEDLINE } \\
\text { (via Pubmed) }\end{array}$ & $\begin{array}{l}\text { (“toothbrush"[All Fields] OR “toothbrushes"[All Fields] OR “toothbrushing”[MeSH Terms] OR "toothbrush- } \\
\text { ing”[All Fields] OR "toothbrushings"[All Fields] OR “Toothbrush contamination”[All Fields]) AND ("covid 19”[All } \\
\text { Fields] OR “covid 19”[MeSH Terms] OR "sars cov 2"[All Fields] OR "sars cov 2"[MeSH Terms] OR "severe acute } \\
\text { respiratory syndrome coronavirus 2"[All Fields]) }\end{array}$ \\
\hline SCOPUS & $\begin{array}{l}\text { (TITLE-ABS-KEY (toothbrush OR toothbrushes OR toothbrushing OR toothbrushing) AND TITLE-ABS-KEY ((covid } \\
\text { 19) OR (sars AND cov 2) OR (severe AND acute AND respiratory AND syndrome AND coronavirus 2))) }\end{array}$ \\
\hline EMBASE & 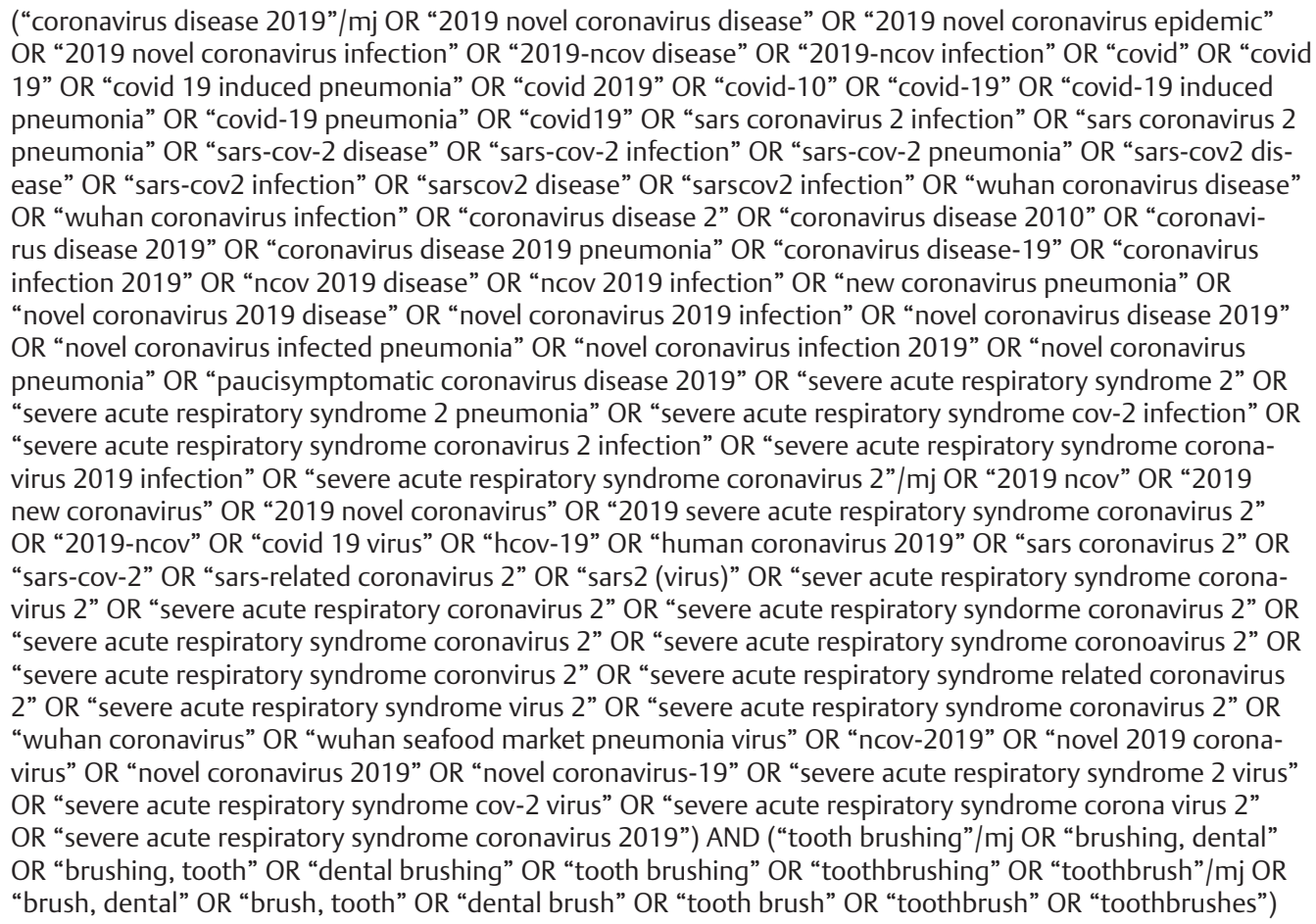 \\
\hline SCIELO & $\begin{array}{l}\text { (toothbrush OR toothbrushes OR toothbrushing OR toothbrushing) AND (sars cov 2) OR (severe acute respira- } \\
\text { tory syndrome coronavirus 2) }\end{array}$ \\
\hline
\end{tabular}




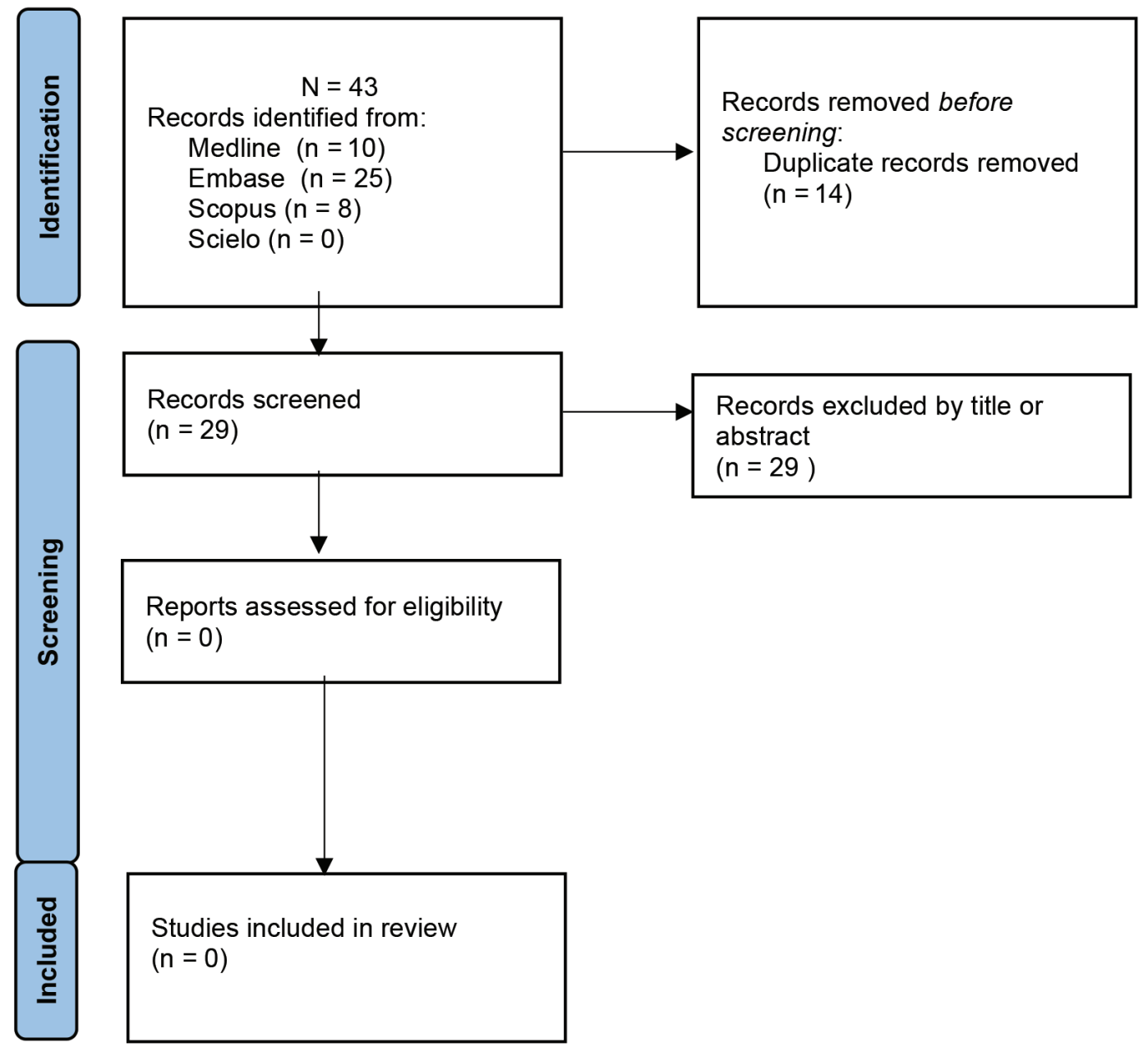

Fig. 1 Prisma flowchart.

with different microorganisms. ${ }^{6,7}$ Previous studies have found proviral DNA on the toothbrush of an HIV-positive patient. ${ }^{21}$ In the same way, HCV-RNA was found in toothbrushes of patients with hepatitis $C^{22}$

Authors have suggested a possible oral-fecal route of SARS-CoV-2 transmission, ${ }^{17,18}$ indicating that toothbrushes placed near toilet seats could be contaminated. ${ }^{17}$ Moreover, it has been reported the presence of Herpes simplex virus type 1 from 48 hours to 7 days on stored toothbrushes, especially in moist environments such as bathrooms. ${ }^{23}$ Similarly, rhinovirus contamination was found in toothbrushes and other home surfaces of people with a common cold. ${ }^{24}$

Earlier studies have demonstrated that toothbrushes could behave as vectors for the transmission and reinfection of viral diseases. ${ }^{8,9}$ It has been reported that cross-contamination of toothbrushes used by human papilloma virus (HPV) patients,,$^{10}$ hepatitis $\mathrm{B},{ }^{11}$ and hepatitis C patients ${ }^{25}$ may occur between family members and inmates who often share the device. ${ }^{26}$ It is essential to emphasize that in the context of COVID-19, some patients did not show any symptoms during the early stage of infection, ${ }^{27,28}$ and infected subjects can spread the disease even before developing symptoms ${ }^{29-31}$ through infected saliva. ${ }^{32-34}$
Recently, González-Olmo et $\mathrm{al}^{4}$ have found that $3 \%$ of cohabitants share toothbrushes, $64.2 \%$ used the same toothbrush container, and $50.3 \%$ the same toothpaste, suggesting that inadequate measures and habits could indirectly contribute to COVID-19 infection between people living together. ${ }^{4}$

Regarding the disinfection and storage of toothbrushes, no experimental studies were found related to SARS-CoV-2 infection. However, concerning other viruses, Devine et $\mathrm{al}^{35}$ demonstrated that tetrasodium EDTA reduces Herpes simplex virus and poliovirus infectivity, suggesting its use to neutralize enveloped and nonenveloped viruses on dental appliances. Other studies have indicated that microwave and ultraviolet (UV) irradiation can effectively disinfect virus-infected toothbrushes. ${ }^{36,37}$ Moreover, ozone, a powerful cellular oxidant, has been considered a promising bactericidal, virucide, and antifungal agent for toothbrushes after 30 minutes of exposure. ${ }^{38}$

Although the real impact of decontaminants on SARS-CoV-2 is still uncertain, it has been suggested that the use of some mouthwashes may reduce the oral viral load, decreasing the risk of transmission and the severity of COVID-19. ${ }^{39,40}$ Different antiseptics, including cetylpyridinium chloride, delmopinol hydrochloride, povidone-iodine, 
and chlorhexidine digluconate, have demonstrated in vitro SARS-CoV-2 inactivation. ${ }^{41-44}$ Lamarca et $\mathrm{al}^{32}$ have emphasized toothbrush disinfection in family and community settings (schools and hospitals) and suggested a hygiene protocol for disinfecting toothbrushes against SARS-CoV-2.

Depending on their storage, toothbrushes can become a source of cross-infection. ${ }^{6} 45$ Studies comparing microbial contamination of toothbrushes used between 1 and 3 months suggested that toothbrushes should be replaced after 3 to 4 weeks. ${ }^{46-48}$ Concerning viral contamination, Glass and Jensen recommended replacing toothbrushes every 2 weeks. ${ }^{49}$ Besides, the storage of toothbrushes in closed containers and close contact with other devices may increase the number of microorganisms. ${ }^{46,50-52}$ In addition, some authors recommended not sharing toothbrushes or toothpaste tubes. ${ }^{4,17}$

\section{Suggested Protocol for Storage and Disinfecting Toothbrushes}

Although evidence has not yet been established, the following recommendations are made as a precautionary measure in the COVID-19 preventive approach:

- Do not share toothbrushes.

- Do not store them in closed containers.

- Disinfection of the toothbrush handle with a proven disinfectant tested against SARS-CoV-2 (in community settings).

- Disinfection of the toothbrush bristles with a proven in vitro oral rinse tested against SARS-CoV 2 for 1 minute.

- Replace toothbrushes every month in uninfected persons living with a polymerase chain reaction (PCR)-positive patient.

- If sharing the restroom with many people, prefer to store toothbrushes in another clean place.

- If a COVID-19 infection is confirmed, replace the toothbrush after 2 weeks, keep it separate, and use a personal toothpaste tube.

\section{Conclusions}

No studies on the possible transmission of SARS-CoV-2 via toothbrushes were identified for inclusion in this review. Although there is no substantial published evidence, studies with other viral diseases have indicated that improper use and storage of toothbrushes could contribute to indirect disease transmission. Therefore, this narrative review supports the implementation of toothbrush disinfection and storage measures to minimize the risk of SARS-CoV-2 infection among cohabitants and community settings. Dentists should educate their patients about this. However, these recommendations urgently need to be validated with studies related to COVID-19.

\section{Conflict of Interest}

The authors do not have any financial interest in the companies whose materials are included in this article.

\section{References}

1 World Health Organization. Advice on the use of masks in the context of COVID-19: interim guidance. Available at: https:// apps.who.int/iris/bitstream/handle/10665/332293/WHO2019-nCov-IPC_Masks-2020.4-eng.pdf. Accessed August 9, 2021

2 Wu F, Zhao S, Yu B, et al. A new coronavirus associated with human respiratory disease in China. Nature 2020;579(7798): 265-269

3 Zheng J. SARS-CoV-2: an emerging Coronavirus that causes a global threat. Int J Biol Sci 2020;16(10):1678-1685

4 González-Olmo MJ, Delgado-Ramos B, Ruiz-Guillén A, Romero-Maroto M, Carrillo-Díaz M. Oral hygiene habits and possible transmission of COVID-19 among cohabitants. BMC Oral Health 2020;20(1):286

5 Glass RT, Conrad RS, Köhler GA, Warren AJ, Bullard JW. Microbiota found in protective athletic mouthguards. Sports Health 2011;3(3):244-248

6 Ankola AV, Hebbal M, Eshwar S. How clean is the toothbrush that cleans your tooth? Int J Dent Hyg 2009;7(4):237-240

7 Frazelle MR, Munro CL. Toothbrush contamination: a review of the literature. Nurs Res Pract 2012;2012:420630

8 Bhat SS, Hegde KS, George RM. Microbial contamination of tooth brushes and their decontamination. J Indian Soc Pedod Prev Dent 2003;21(3):108-112

9 Glass RT. The infected toothbrush, the infected denture, and transmission of disease: a review. Compendium 1992;13(7):592-594, 596-598

10 Cook RL, Thompson EL, Kelso NE, et al. Sexual behaviors and other risk factors for oral human papillomavirus infections in young women. Sex Transm Dis 2014;41(8):486-492

11 Okonkwo UC, Okpara H, Otu A, et al. Prevalence of hepatitis B, hepatitis $C$ and human immunodeficiency viruses, and evaluation of risk factors for transmission: Report of a population screening in Nigeria. S Afr Med J 2017;107(4):346-351

12 Hamming I, Timens W, Bulthuis ML. Lely AT, Navis G, van Goor $\mathrm{H}$. Tissue distribution of ACE2 protein, the functional receptor for SARS coronavirus. A first step in understanding SARS pathogenesis. J Pathol 2004;203(2):631-637

$13 \mathrm{Xu} \mathrm{H}$, Zhong L, Deng J, et al. High expression of ACE2 receptor of 2019-nCoV on the epithelial cells of oral mucosa. Int J Oral Sci 2020;12(1):8

14 Li Y, Ren B, Peng X, et al. Saliva is a non-negligible factor in the spread of COVID-19. Mol Oral Microbiol 2020;35(4):141-145

15 To KK, Tsang OT, Yip CC, et al. Consistent detection of 2019 novel Coronavirus in saliva. Clin Infect Dis 2020;71(15):841-843

16 Sabino-Silva R, Jardim ACG, Siqueira WL. Coronavirus COVID19 impacts to dentistry and potential salivary diagnosis. Clin Oral Investig 2020;24(4):1619-1621

17 Patel J. A plausible transmission mode. $\mathrm{Br}$ Dent J 2020;228(10):735

18 Deidda S, Tora L, Firinu D, et al. Gastrointestinal coronavirus disease 2019: epidemiology, clinical features, pathogenesis, prevention, and management. Expert Rev Gastroenterol Hepatol 2021;15(1):41-50

19 van Doremalen N, Bushmaker T, Morris DH, et al. Aerosol and surface stability of SARS-CoV-2 as compared with SARSCoV-1. N Engl J Med 2020;382(16):1564-1567

20 Santarpia JL, Rivera DN, Herrera VL, et al. Aerosol and surface contamination of SARS-CoV-2 observed in quarantine and isolation care. Sci Rep 2020;10(1):12732

21 Glass RT, Carson SR, Barker RL, Peiper SC, Shapiro S. Detection of HIV proviral DNA on toothbrushes: a preliminary study. J Okla Dent Assoc 1994;84(3):17-20

22 Lock G, Dirscherl M, Obermeier F, et al. Hepatitis C - contamination of toothbrushes: myth or reality? J Viral Hepat 2006;13(9):571-573 
23 Glass RT, Lare MM. Toothbrush contamination: a potential health risk. ? Quintessence Int 1986;17(1):39-42

24 Winther B, McCue K, Ashe K, Rubino J, Hendley JO. Rhinovirus contamination of surfaces in homes of adults with natural colds: transfer of virus to fingertips during normal daily activities. J Med Virol 2011;83(5):906-909

25 Akhtar S, Moatter T, Azam SI, Rahbar MH, Adil S. Prevalence and risk factors for intrafamilial transmission of hepatitis $C$ virus in Karachi, Pakistan. J Viral Hepat 2002;9(4):309-314

26 Crowley D, Lambert JS, Betts-Symonds G, et al. The seroprevalence of untreated chronic hepatitis $\mathrm{C}$ virus (HCV) infection and associated risk factors in male Irish prisoners: a cross-sectional study, 2017. Euro Surveill 2019;24(14):1800369

27 Hemida MG, Ba Abduallah MM. The SARS-CoV-2 outbreak from a one health perspective. One Health 2020;10:100127

28 Nishiura H, Kobayashi T, Miyama T, et al. Estimation of the asymptomatic ratio of novel coronavirus infections (COVID19. Int J Infect Dis 2020;94:154-155

29 Rothe C, Schunk M, Sothmann P, et al. Transmission of 2019$\mathrm{nCoV}$ infection from an asymptomatic contact in Germany. N Engl J Med 2020;382(10):970-971

30 Akram MZ. Inanimate surfaces as potential source of 2019nCoV spread and their disinfection with biocidal agents. Virusdisease 2020;31(2):94-96

31 Wölfel R, Corman VM, Guggemos W, et al. Virological assessment of hospitalized patients with COVID-2019. Nature 2020;581(7809):465-469

32 Lamarca JH, de Carvalho FG, Machado FC, Lacerda Dos Santos R, Barbosa TS. Severe acute respiratory syndrome Coronavirus 2: a protocol for disinfection of toothbrushes. J Infect Dis 2021;223(6):1113-1114

33 Basman A, Peker I, Akca G, Alkurt MT, Sarikir C, Celik I. Evaluation of toothbrush disinfection via different methods. Braz Oral Res 2016;30:S1806-83242016000100203 doi: 10.1590/1807-3107BOR-2016.vol30.0006

34 Merchán I, Merino-Alado RL, Briceño EN, et al. An in vitro effectiveness evaluation of chemical agents for toothbrushes disinfection. Pesqui Bras Odontopediatria Clin Integr 2019;19:e4296

35 Devine DA, Percival RS, Wood DJ, et al. Inhibition of biofilms associated with dentures and toothbrushes by tetrasodium EDTA. J Appl Microbiol 2007;103(6):2516-2524

36 Devine DA, Keech AP, Wood DJ, et al. Ultraviolet disinfection with a novel microwave-powered device. J Appl Microbiol 2001;91(5):786-794

37 Glass RT, Jensen HG. The effectiveness of a u-v toothbrush sanitizing device in reducing the number of bacteria, yeasts and viruses on toothbrushes. J Okla Dent Assoc 1994;84(4):24-28
38 Bezirtzoglou E, Cretoiu SM, Moldoveanu M, Alexopoulos A, Lazar V, Nakou M. A quantitative approach to the effectiveness of ozone against microbiota organisms colonizing toothbrushes. J Dent 2008;36(8):600-605

39 Vergara-Buenaventura A, Castro-Ruiz C. Use of mouthwashes against COVID-19 in dentistry. Br J Oral Maxillofac Surg 2020;58(8):924-927

40 Herrera D, Serrano J, Roldán S, Sanz M. Is the oral cavity relevant in SARS-CoV-2 pandemic? Clin Oral Investig 2020;24(8):2925-2930

41 Komine A, Yamaguchi E, Okamoto N, Yamamoto K. Virucidal activity of oral care products against SARS-CoV-2 in vitro. J Oral Maxillofac Surg Med Pathol 2021;33(4):475-477

42 Hassandarvish P, Tiong V, Mohamed NA, et al. In vitro virucidal activity of povidone iodine gargle and mouthwash against SARS-CoV-2: implications for dental practice. Br Dent J 2020;1-4 doi: 10.1038/s41415-020-2402-0

43 Castro-Ruiz C, Vergara-Buenaventura A. Povidone-iodine solution: a potential antiseptic to minimize the risk of COVID19? A narrative review. J Int Soc Prev Community Dent 2020;10(6):681-685

44 Jain A, Grover V, Singh C, et al. Chlorhexidine: an effective anticovid mouth rinse. J Indian Soc Periodontol 2021;25(1):86-88

45 Nascimento AP, Faria G, Watanabe E, Ito IYJ. Efficacy of mouthrinse spray in inhibiting cariogenic biofilm formation on toothbrush bristles. Braz J Oral Sci 2008;7(24):1489-1495

46 Raiyani CM, Arora R, Bhayya DP, Dogra S, Katageri AA, Singh V. Assessment of microbial contamination on twice a day used toothbrush head after 1-month and 3 months: An in vitro study. J Nat Sci Biol Med 2015;6(Suppl 1):S44-S48

47 Contreras A, Arce R, Botero JE, Jaramillo A, Betancourt M. Toothbrush contamination in family members. Rev Clin 2010;3(1):24-26

48 Ferreira CA, Savi GD, Panatto AP, Generoso JDS, Barichello T. Microbiological evaluation of bristles of frequently used toothbrushes. Dental Press J 2012;17(4):72-76

49 Glass RT, Jensen HG. More on the contaminated toothbrush: the viral story. Quintessence Int 1988;19(10):713-716

50 Sowmya KR, Puranik MP, James JM, Sabbarwal B. Perceptions about toothbrush contamination and disinfection among dental students in Bengaluru City: A cross-sectional study. Indian J Dent Res 2017;28(6):646-649

51 Medina-Patruno C, Bolaños-Rivero M, Martin-Sanchez AM, Saavedra-Santana P, Vicente-Barrero M. ¿ Cuál es el nivel de contaminación del cepillo de dientes almacenado en diferentes entornos sanitarios? Av Odontoestomatol 2019;35(2):69-72

52 Mehta A, Sequeira PS, Bhat G. Bacterial contamination and decontamination of toothbrushes after use. N Y State Dent J 2007;73(3):20-22 